\title{
Impact of Sand Dredging Activities on Ecosystem and Community Survival in Ibeshe Area of Lagos Lagoon, Nigeria
}

\author{
Falilu Olaiwola Adekunbi1 ${ }^{*}$, Isa Olalekan Elegbede², Dorathy Iniobong Akhiromen1, \\ Theresa Osamudiame Oluwagunke ${ }^{1}$, Opeyemi Otolorin Oyatola ${ }^{1}$ \\ ${ }^{1}$ Nigerian Institute for Oceanography and Marine Research, Victoria Island, Lagos, Nigeria \\ ${ }^{2}$ Environmental Resource Management, Brandenburg University of Technology, Cottbus-Senftenberg, Germany \\ Email: *kunbiphisch@gmail.com
}

How to cite this paper: Adekunbi, F.O., Elegbede, I.O., Akhiromen, D.I., Oluwagunke, T.O. and Oyatola, O.O. (2018) Impact of Sand Dredging Activities on Ecosystem and Community Survival in Ibeshe Area of Lagos Lagoon, Nigeria. Journal of Geoscience and Environment Protection, 6, 112-125.

https://doi.org/10.4236/gep.2018.62008

Received: January 16, 2018

Accepted: February 25, 2018

Published: February 28, 2018

Copyright $\odot 2018$ by authors and Scientific Research Publishing Inc. This work is licensed under the Creative Commons Attribution International License (CC BY 4.0).

http://creativecommons.org/licenses/by/4.0/

\section{(c) (i) Open Access}

\begin{abstract}
This study investigates the impact of sand dredging activities on coastal ecosystem and community survival around Ibeshe area of the Lagos Lagoon, $\mathrm{Ni}$ geria. Surface water and bottom sediment samples were collected from locations partitioned into Dredged Area (DA) and Undredged Area (UA) in the lagoon for laboratory analyses. Questionnaires were administered to community dwellers and sand miners to further analyze perception of locals. Significant differences in water quality parameters and sediments properties from Dredged and Undredged areas, and highly significant relationship between sand dredging and unsustainable ecological practices in Ibeshe were observed. One way ANOVA test indicates that all water quality parameters measured with exception of turbidity and nitrate concentration were not significantly different $(P>0.05)$ between Dredged and Undredged area. With exception of moisture content other sediment parameters measured were not significantly different $(\mathrm{P}>0.05)$ between Dredged and Undredged areas. The project also determined the impact of dredging activities on the fisheries and fishing business in the environment. Turbidity values revealed that fishes will be negatively affected due to dredging activities; moreover dwellers pay little or no attention to conservation of the area due to unawareness. Sand dredging operations negatively influence ecological resources and water composition of the area. This project is designed to randomly sample the opinion of sand mining operators and residents; and questionnaires were administered to obtain data. Strict regulation and enforcement will assist to control ecological destruction and solve problems facing the lagoon environment.
\end{abstract}

\section{Keywords}

Physico-Chemical Parameters, Lagoon, Anthropogenic Activities, Sand Mining 


\section{Introduction}

Dredging entails the excavation of material from sea, river or lake beds and its relocation elsewhere; it is a necessary activity in infrastructural development. Amongst others, it improves navigable depths in ports, harbours and shipping channels, water and flood management, creation of new lands and habitats, and derivation of minerals from underwater deposits which is crucial for sustainable development of nature resources, economic values and quality of life [1].

Impacts of dredging on water column due to excavation and bottom sediments removal include, increase in turbidity which is consequent to the resuspension of sediments [2]. Other impacts may result from the dredging of polluted areas with an associated release of anoxic bottom sediments to the surface, leading to the oxidation of metal sulphides [3]. Biologically available cations are released in this process, a common phenomenon observed in estuaries subjected to dredging [3] [4] [5] [6]. This mobilisation process impacts estuarine water systems due to the persistent toxicity effects of a number of trace elements [6] [7].

Emerging increase in anthropogenic pressures, including dredging of estuarine systems, warrants the development of physical, biological and chemical indicators of water quality and ecological change for effective policy implementations in aquatic systems [8]. Phytoplankton are efficient and easily detectable indicators of water and ecological change due to their sensitivity to several environmental stressors [9].

Ecological impacts emanating from the dredging of vulnerable environments are damages to flora and fauna, topographic and hydrological alterations coupled with water quality impairments. Zooplankton, phytoplankton, benthic invertebrates and vegetation are other components of the aquatic environment affected by dredging activities [10] [11] [12] [13]. The socio-economic functions of coastal environments are also often hampered by dredging operations thus creating ecosystem imbalance.

Sediment characteristics are a determinant factor in contamination of dredged marine environments. This is due to the retention and adsorption of contaminants to sediments by contaminants that have settled on the bottom of marine water beds [14]. Sediments retain nutrients, including N and P [15]. Metals; Zn, $\mathrm{Hg}, \mathrm{Cd}, \mathrm{As}, \mathrm{Pb}, \mathrm{Cu}$ and $\mathrm{Ni}$ are retained and transported by sediments. Transportation of contaminants by sediments is dependent on several factors, primarily particle size [16]. Ocean and wetland systems, tides, currents and waves can be attributed to sediments transportation [17] [18].

Mangrove zones bordering estuarine environments are characterized by sediments and soils rich in iron sulphides [19]. Exposing these sulphide-containing sediments through dredging initiate oxidative reactions results in acidification of estuarine environments [20]. Acidifications of estuarine systems have been implicated as the cause of death in fish, vegetation, and change in water quality, and contamination by heavy metals [21] [22] [23].

Although resuspension of sediments and subsequent increased turbidity 
brought about by dredging enhances the attenuation of light thus influencing phytoplankton abundance, this factor might not be critical to hinder phytoplankton productivity in dredged areas [24]. Phytoplankton community structure has been found to be reconfigured, favouring the dominance of benthic diatoms thriving in water column as a result of suspended particulate matter that occur during dredging. High benthic: pelagic diatom ratio has been found to be prevalent in perturbed areas [25].

Nigeria is a developing country whose urban cities, particularly Lagos, are expanding at a high rate, thus sand dredging will continue to be a major source for land reclamation purpose and building materials for housing development. Consequently, sand dredging operations would still be very much relevant to the construction industry in Lagos state in actualizing its mega city pursuit and will remain so for several years.

Monitoring the dynamics of marine environments with respect to effects of dredging is necessary to evaluate as well as to predict its long-term physical and chemical stability. This could be accomplished by considering the results of parameters collected in pre-dredging and dredging phases. However, a more inclusive phase should be post-dredging phase, to establish the recuperative capability of marine environments and adjoining coastal areas to their natural state after dredging operations.

Ibeshe is one of the important coastal communities around Ikorodu waterfront characterized by several years of sand wining using manual or mechanical dredging operations; artisanal fisheries and transportation. However, over the years dredging of the lagoon has been a profit oriented activity with detrimental consequence on the environment. Apparently, impacts are destruction of wetlands and mangrove swamps, persistent water turbidity, disappearance of certain phytoplankton and zooplankton, including several species of macro-benthos which ultimately affect fishery production and distribution.

Limited studies exist on impacts of dredging activities on marine environments, particularly on the composition of water during the course of dredging operation. In addition, paucity of information on fisheries responses, distribution and abundance in the Lagos lagoon poses challenges which demands urgent observation. The present study seek to investigate the impacts of sand dredging on the ecology of Lagos lagoon in Ibeshe coastal community area, viz-a-viz its influence on water composition, fish and fisheries distribution as well as the perception of coastal community dwellers to environmental effects of sand dredging are discussed.

\section{Materials and Methods}

\subsection{Study Area}

Ibeshe coastal community is located along Lagos Lagoon in Ikorodu, Lagos state on the Southwestern part of Nigeria coastline within longitude $3.47^{\circ}$ to $3.29^{\circ} \mathrm{E}$ and latitude $6.55^{\circ}$ to $6.41^{\circ}$ (Figure 1). The lagoon has a wide catchment with its 


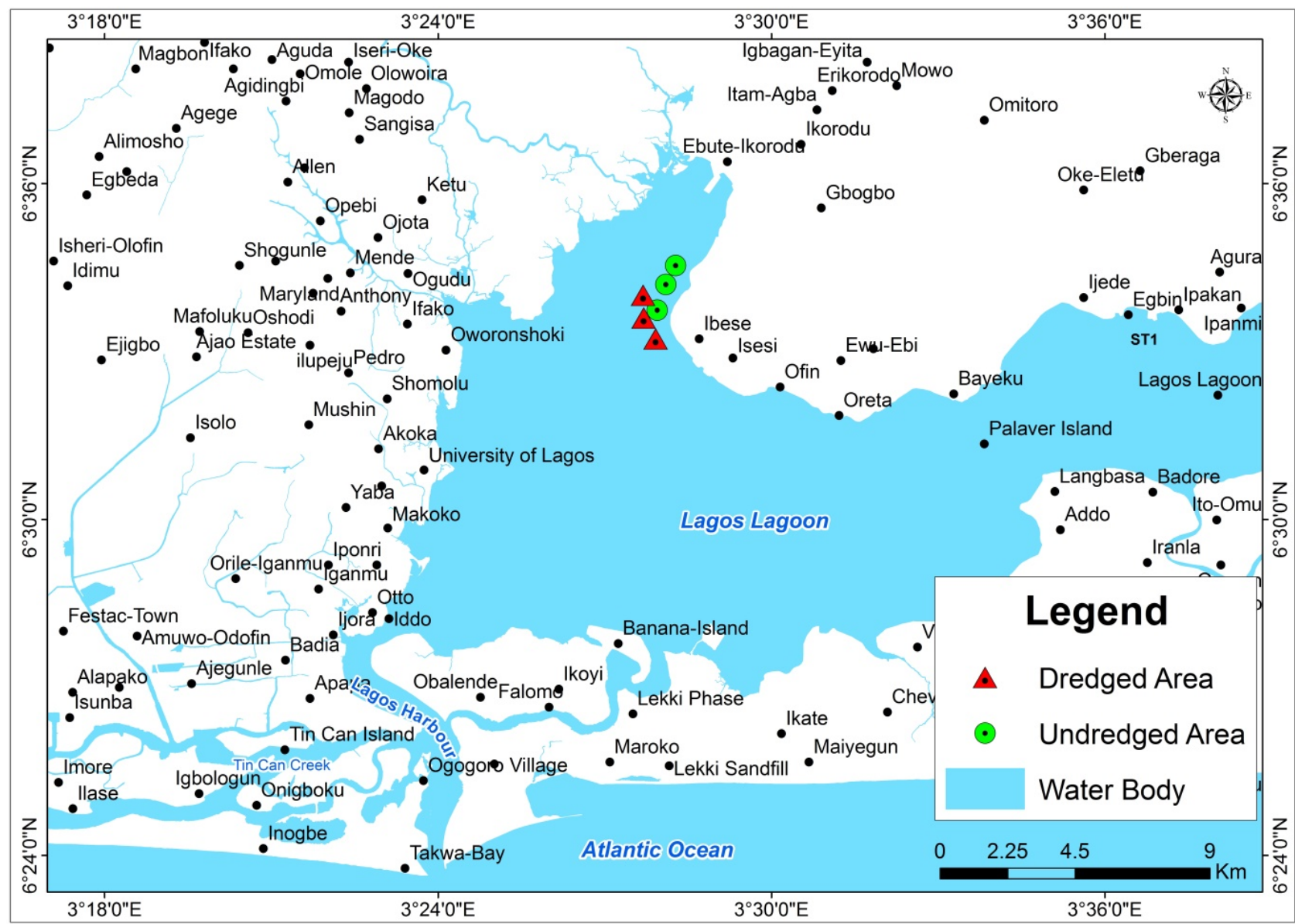

Figure 1. Map of study area showing sampling sites (Source: Nigerian institute for oceanography and marine research).

major source from River Owuru and flows into Lagos Lagoon at Ipakodo from where it receives tidal influence. The lagoon is utilized for multiple purposes including artisanal fishing, sand mining, transportation and domestic uses.

\subsection{Sample Collection and Analyses}

In other to establish biophysical status of the study area, collection of sediments and surface water samples were made at six sampling locations. Soil sample was collected at North East of Kudos Engineering Company (one of the existing dredging company operating in Ibeshe water front). Locally made boat was used as means of transport on the lagoon and the samples were collected at three different locations within the lagoon for both the Dredged area and Undredged area. Three Samples (sediments and waste water) for the Undredged area was first collected within the same location, the first sample for the Undredged area was taken at a depth of $1.95 \mathrm{~m}$ with major coordinate Latitude $6^{\circ} 34^{\prime} 32.132^{\prime \prime}$ and Longitude $3^{\circ} 28^{\prime} 16.59^{\prime \prime}$, second sample was taken at $2.13 \mathrm{~m}$ depth with major coordinate Latitude $6^{\circ} 34^{\prime} 29.694^{\prime \prime}$ and Longitude $3^{\circ} 28^{\prime} 11.899^{\prime \prime}$ at a distance $159 \mathrm{~m}$ apart. The third sample for the Undredged area was collected at a depth of 2.66 $\mathrm{m}$ with coordinate Latitude $6^{\circ} 34^{\prime} 32.074^{\prime \prime}$ and Longitude $3^{\circ} 28^{\prime} 8.645^{\prime \prime}$ at a distance 
of $128 \mathrm{~m}$ from the second point, the depth of sample collected was determined with the aid of a meter rule that was deep into the lagoon. Soil sample collected manually by divers, was immediately kept in polythene bags to prevent atmospheric and other environmental interactions. Waste water was also collected in this location with a white plastic keg to determine the physico-chemical quality of the water.

Samples for Dredged area were collected from a dredger that was in operation and discharging sand into a barge. The depths of the samples collected were determined from the dredger machine. The first sample collected for the Dredged area was taken at a depth of $11.3 \mathrm{~m}$ with coordinate Latitude $6^{\circ} 34^{\prime} 37.292^{\prime \prime}$ and Longitude $3^{\circ} 28^{\prime} 0.997^{\prime \prime}$, second samples was collected at a depth of $19.0 \mathrm{~m}$ with coordinates Latitude $6^{\circ} 34^{\prime} 26.36^{\prime \prime}$ and Longitude $3^{\circ} 28^{\prime} 25.051^{\prime \prime}$ at a distance of 812 $\mathrm{m}$ apart. The third sample was taken at a depth of $15 \mathrm{~m}$ with coordinate Latitude $6^{\circ} 34^{\prime} 30.627^{\prime \prime}$ and Longitude $3^{\circ} 28^{\prime} 23.72^{\prime \prime}$ at a distance of $140 \mathrm{~m}$ from the second location. Water samples were also collected at these locations to determine the quality of the water. The samples collected for first sediments and waste water was taken to the laboratory to determine heavy metals in the sediments and hardness. Chemical Oxygen Demand (COD) and Biological Oxygen Demand (BOD) were also determined. Sample analyses were carried out for surface water and bottom sediment, using [26] method and [27] methods respectively.

The results obtained from the analyses carried out above was compared to LASEPA standard to determine if the impact of dredging activities in the lagoon is of low, intensive or high impact on the environment.

\subsection{Questionnaire Administration}

Questionnaires were administered to Ibeshe coastal community dwellers to access the perception of dredging activities in their community. Fifty (50) questionnaires were administered and were all retrieved on the field to preclude loss of information from any of the respondents. Responses from the administered questionnaires collected were interpreted with the aid of statistical representation (pie charts), Figures 2(a)-(h).

\subsection{Statistical Analysis}

Physico-chemical data were classified accordingly and were compared for variability using one-way Analysis of Variance (ANOVA). We assumed a normally distributed variables since observations were maintained at same geographical location throughout the sampling periods. Also, to better explain higher ordered interaction expected in this study, Pearson's product moment correlation coefficient was used to evaluate relationships among the variables.

\section{Results}

\subsection{Water Quality}

Water quality parameters of Dredged and Undredged area of the lagoon are 


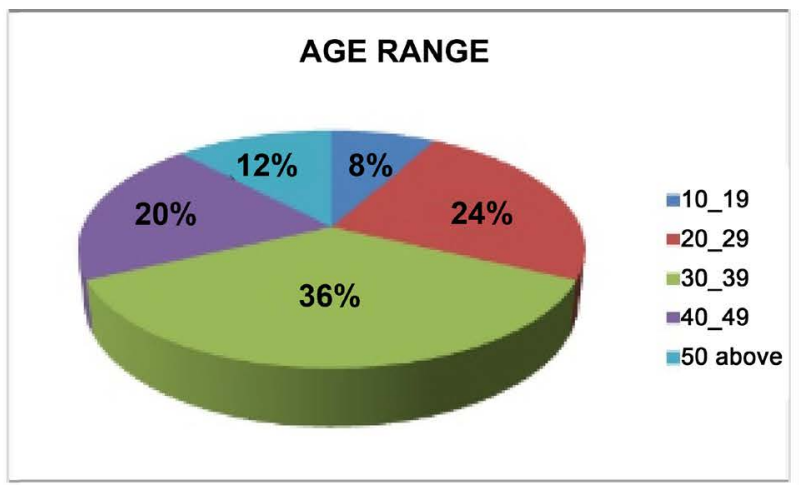

(a)

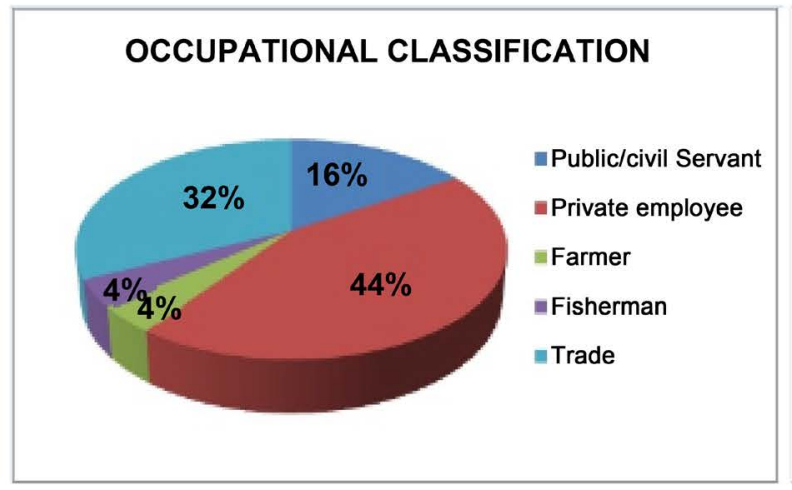

(c)

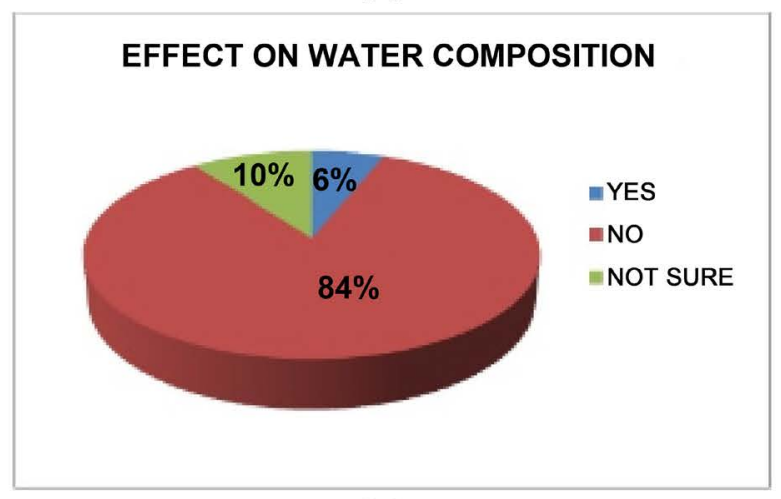

(e)

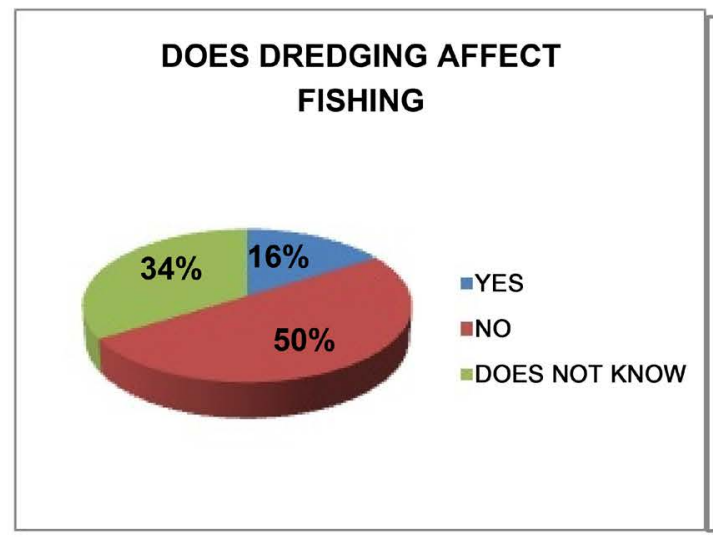

(g)

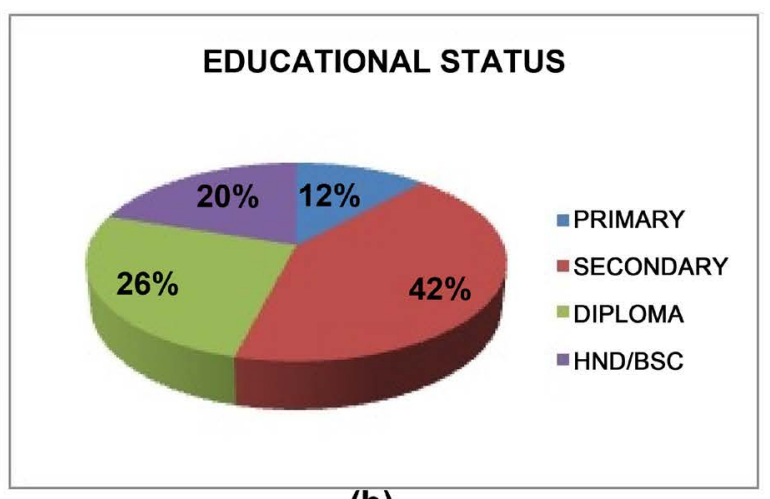

(b)

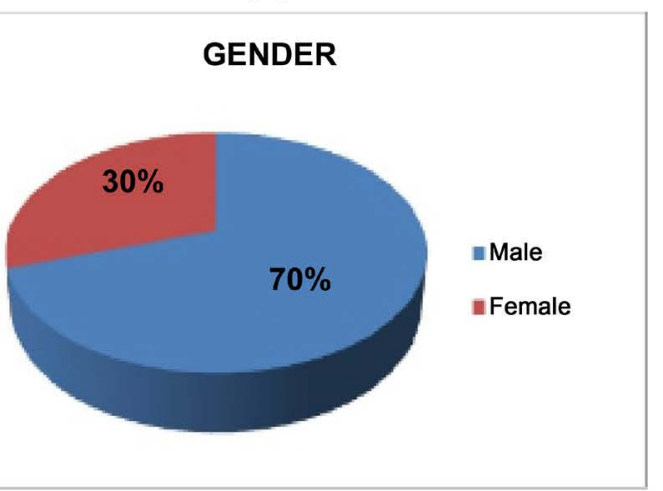

(d)

\section{SOCIAL/ENVIRONMENT EFFECT}

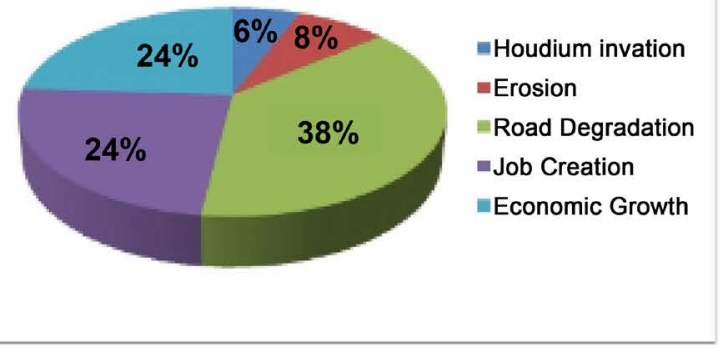

(f)

\section{Source of Drinkable Water}

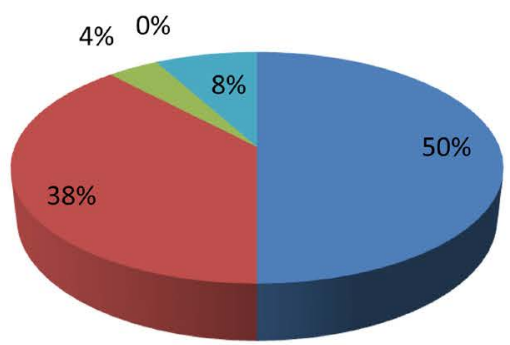

Tap

Well

Spring

lagoon

satchet

(h)

Figure 2. Pie-chart representation of respondents. 
Table 1. Values of water quality parameters in dredged and undredged areas in Ibeshe section of Lagoon, Lagos in relation to LASEPA standard.

\begin{tabular}{|c|c|c|c|c|}
\hline Parameters & $\mathbf{N}$ & $\begin{array}{l}\text { Undredged } \\
\text { Mean } \pm \text { SD }\end{array}$ & $\begin{array}{c}\text { Dredged } \\
\text { Mean } \pm S D\end{array}$ & $\begin{array}{l}\text { LASEPA } \\
\text { Standard }\end{array}$ \\
\hline Colour & 3 & $180.7 \pm 145.5$ & $290.3 \pm 107.8$ & 250 Pt.Co.APHA \\
\hline Temperature & 3 & $25.7 \pm 1.7$ & $25.9 \pm 1.2$ & 40 \\
\hline $\mathrm{pH}$ & 3 & $6.7 \pm 1.7$ & $7.3 \pm 1.3$ & $5.5-9.0$ \\
\hline Turbidity & 3 & $16.9 \pm 2.2$ & $23.1 \pm 0.5$ & FTU \\
\hline Conductivity & 3 & $70.2 \pm 8.5$ & $82.4 \pm 19.0$ & $\mu \mathrm{S} / \mathrm{cm}$ \\
\hline Total suspended solid & 3 & $24.0 \pm 15.1$ & $2.7 \pm 3.2$ & $100 \mathrm{mg} / \mathrm{l}$ \\
\hline Total dissolved solid & 3 & $114.7 \pm 99.3$ & $155.3 \pm 49.1$ & $2100 \mathrm{mg} / \mathrm{l}$ \\
\hline Total solid & 3 & $138.7 \pm 110.4$ & $178.0 \pm 49.5$ & $2200 \mathrm{mg} / \mathrm{l}$ \\
\hline Total acidity (mg/l) & 3 & $36.0 \pm 6.1$ & $50.3 \pm 7.5$ & NS \\
\hline Total alkalinity (mg/l) & 3 & $86.7 \pm 46.2$ & $90.0 \pm 39.1$ & NS \\
\hline Chloride & 3 & $29.7 \pm 4.7$ & $29.3 \pm 5.9$ & $250 \mathrm{mg} / \mathrm{l}$ \\
\hline Nitrate & 3 & $1.3 \pm 0.2$ & $0.3 \pm 0.3$ & - \\
\hline Phosphate & 3 & $1.1 \pm 0.1$ & $1.5 \pm 0.3$ & - \\
\hline Sulphate & 3 & $4.0 \pm 1.0$ & $4.3 \pm 2.3$ & - \\
\hline Phenol & 3 & $0.0 \pm 0.0$ & $0.0 \pm 0.0$ & $1.0 \mathrm{mg} / \mathrm{l}$ \\
\hline Oil and Grease & 3 & $0.0 \pm 0.0$ & $0.0 \pm 0.0$ & $10.0 \mathrm{mg} / \mathrm{l}$ \\
\hline Dissolved oxygen & 3 & $5.5 \pm 0.3$ & $5.5 \pm 0.5$ & Not Less than 2 \\
\hline COD & 3 & $0.3 \pm 0.6$ & $0.0 \pm 0.0$ & $200 \mathrm{mg} / \mathrm{l}$ \\
\hline BOD & 3 & $0.1 \pm 0.1$ & $0.0 \pm 0.0$ & $50 \mathrm{mg} / 1$ \\
\hline Iron & 3 & $0.3 \pm 0.3$ & $0.5 \pm 0.4$ & $10.0 \mathrm{mg} / \mathrm{l}$ \\
\hline Sodium & 3 & $1.5 \pm 0.4$ & $2.4 \pm 1.9$ & - \\
\hline Potassium & 3 & $0.4 \pm 0.1$ & $0.3 \pm .0 .5$ & $200.00 \mathrm{mg} / \mathrm{l}$ \\
\hline Total Plate Count & 3 & $73.3 \pm 49.2$ & $143.3 \pm 77.7$ & $0.5 \mathrm{mg} / \mathrm{l}$ \\
\hline
\end{tabular}

One-way ANOVA test indicates that all sediment sample parameters measured with exception of moisture content were not significantly different $(\mathrm{P}>0.05)$ between Dredged and Undredged areas.

presented in Table 1. Temperature, dissolved oxygen (DO), Chloride, sulphate and heavy metals ( $\mathrm{Fe}, \mathrm{Zn}, \mathrm{Cd}, \mathrm{Ni}, \mathrm{Cu}, \mathrm{Hg}, \mathrm{Pb}$ and $\mathrm{Mn}$ ), surface profile across the sampling areas was homogenous in Dredged and Undredged areas, whereas Colour, turbidity, conductivity, Total solid (TS), Total dissolved solid (TDS), Total suspended solids (TSS) varied and often peaked in dredged areas. One-way ANOVA test indicates that all water quality parameters measured with exception of Turbidity and Nitrate concentration were not significantly different $(P>0.05)$ between Dredged and Undredged areas.

\subsection{Sediment Samples}

Sediment samples showed similar trend as in water samples with values of tem- 
perature, nitrate and other parameters in Dredged and Undredged areas. One-way ANOVA test indicates that all sediment sample parameters measured with exception of moisture content were not significantly different $(\mathrm{P}>0.05)$ between Dredged and Undredged areas.

Natural waters normally contain very small quantities of several essential metals including $\mathrm{Fe}, \mathrm{Cu}, \mathrm{Ni}, \mathrm{Mn}, \mathrm{Zn}$, and $\mathrm{Co}$. Aquatic organisms require these metals in trace amount, hence are referred to as trace elements or micronutrients. These metals become toxic when represent in relatively high concentrations and are non-biodegradable but are easily assimilated and bioaccumulates in aquatic organisms. However, the values of the metals in the water-body were in concentration below the LASEPA acceptable limit.

Table 2 gives the descriptive statistics of the results of the investigated heavy metals in the sediments from the study area. Nine (9) heavy metals were considered for indicator of pollution, and $\mathrm{Pb}$ was the most abundant with average value of $9.68 \mathrm{mg} / \mathrm{kg}$ as against recorded average value of $6.45 \mathrm{mg} / \mathrm{kg}$ lead metal during pre-dredging phase from this environment.

\subsection{Inter-Correlation of Variables}

We evaluate the relations between variables in Dredged and Undredged areas using Pearson Product Moment Correlations coefficient (Table 3). TSS only showed positive correlation with $\mathrm{COD}(\mathrm{r}=0.882 ; \mathrm{P}=0.05 ; \mathrm{n}=6)$ and $\mathrm{BOD}(\mathrm{r}=$

Table 2. Values of parameters in sediments of dredged and undredged areas in Ibeshe section of Lagoon, Lagos in relation to LASEPA standard.

\begin{tabular}{|c|c|c|c|c|}
\hline Parameters & $\mathbf{N}$ & Undredged Mean \pm SD & Dredged Mean $\pm S D$ & LASEPA Standard \\
\hline Temperature & 3 & $28.83 \pm 0.15$ & $28.80 \pm 0.30$ & $35-40$ \\
\hline $\mathrm{pH}$ & 3 & $7.21 \pm 0.08$ & $7.40 \pm 0.14$ & $6.0-9.0$ \\
\hline Conductivity & 3 & $0.26 \pm 0.13$ & $0.14 \pm 0.06$ & $0.1 \mu \mathrm{S} / \mathrm{cm}$ \\
\hline Nitrate & 3 & $2.34 \pm 2.00$ & $1.60 \pm 2.19$ & $250 \mathrm{mg} / \mathrm{kgN}$ \\
\hline Phosphate & 3 & $0.48 \pm 0.41$ & $0.37 \pm 2.12$ & $150 \mathrm{mg} / \mathrm{kgp}$ \\
\hline Sulphate & 3 & $7.67 \pm 4.72$ & $7.00 \pm 9.64$ & $300 \mathrm{mg} / \mathrm{kgS}$ \\
\hline Zinc & 3 & $0.59 \pm 0.95$ & $0.29 \pm 0.49$ & $<1$ \\
\hline Copper & 3 & $0.04 \pm 0.44$ & $0.02 \pm 0.00$ & NS \\
\hline Iron & 3 & $0.00 \pm 0.02$ & $0.00 \pm 0.00$ & $5 \mathrm{mg} / \mathrm{kg} \mathrm{Fe}$ \\
\hline Manganese & 3 & $0.13 \pm 0.16$ & $0.36 \pm 0.52$ & NS \\
\hline Lead & 3 & $9.73 \pm 6.45$ & $9.68 \pm 13.24$ & $5.0 \mathrm{mg} / \mathrm{kg}$ \\
\hline Potassium & 3 & $0.02 \pm 0.03$ & $0.11 \pm 0.11$ & $725 \mathrm{mg} / \mathrm{kg} \mathrm{k}$ \\
\hline Nickel & 3 & $0.02 \pm 0.03$ & $0.02 \pm 0.03$ & NS \\
\hline Moisture & 3 & $1.07 \pm 0.22$ & $0.15 \pm 0.05$ & 0.250 \\
\hline$\%$ Organic Carbon & 3 & $58.05 \pm 1.11$ & $59.39 \pm 0.61$ & NS \\
\hline$\%$ Organic Matter & 3 & $407.38 \pm 533.23$ & $100.95 \pm 1.05$ & $>6$ \\
\hline
\end{tabular}


Table 3. Pearson correlation matrix of water quality parameters in dredged and undredged area.

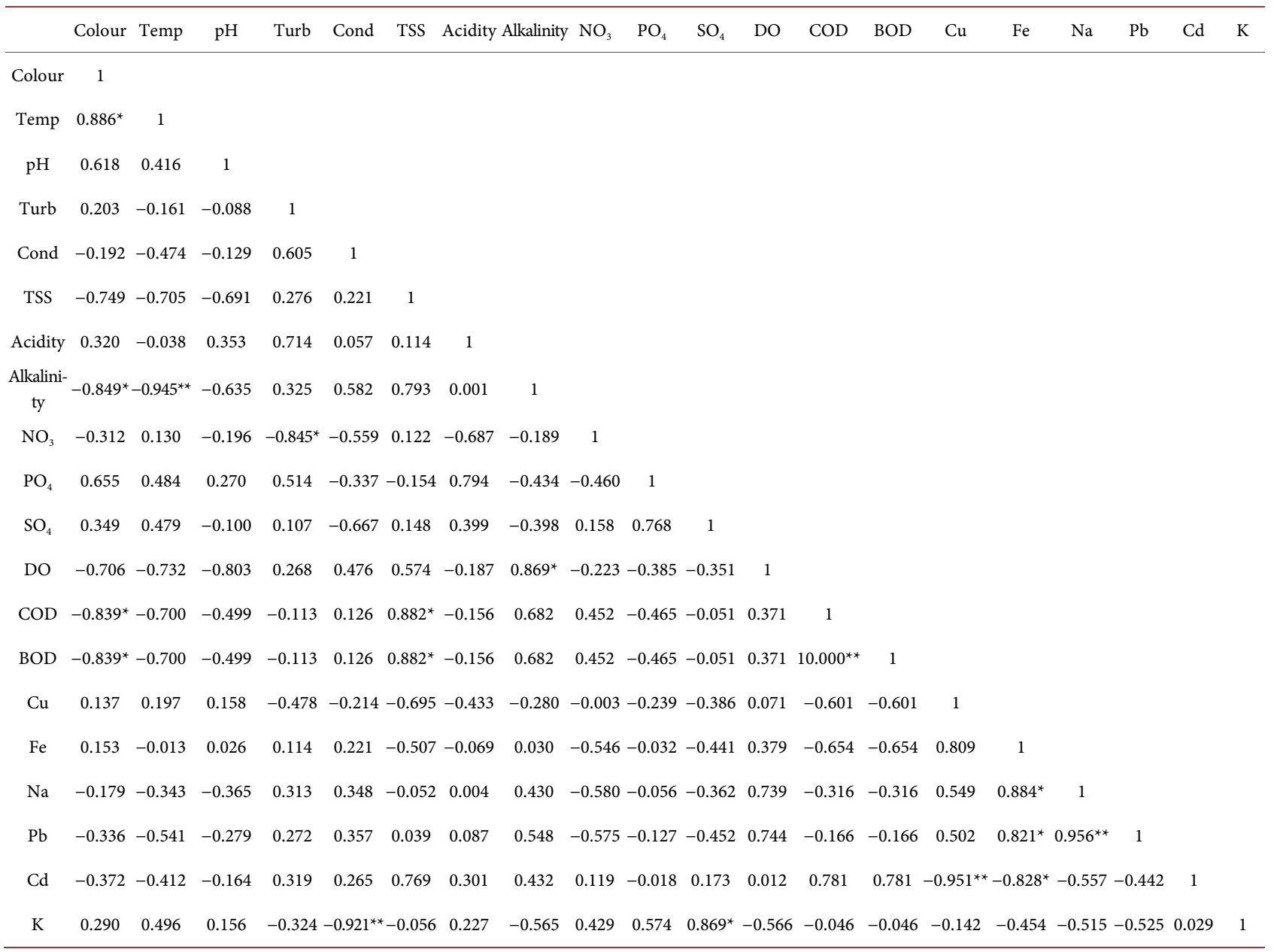

${ }^{*}$ Correlation is significant at the 0.05 level (2-tailed). ${ }^{*}$ Correlation is significant at the 0.01 level (2-tailed). $\mathrm{N}=6$.

$0.885, \mathrm{P}=0.05 ; \mathrm{n}=6)$, whereas, colour showed negative correlation with COD $(\mathrm{r}$ $=0.839 ; \mathrm{P}=0.01 ; \mathrm{n}=6), \mathrm{BOD}(\mathrm{r}=-0.839 ; \mathrm{P}=0.05 ; \mathrm{n}=6)$ and alkalinity $(\mathrm{r}=$ $-0.526 ; \mathrm{P}=0.05 ; \mathrm{n}=6)$. Turbidity showed negative correlation with nitrate $(\mathrm{r}=$ $-0.845, \mathrm{P}=0.05 ; \mathrm{n}=6$ ). Since most nitrogen loading into aquatic systems has often been implicated with anthropogenic influence, stronger correlation between nitrate and turbidity may suggest some influence from mining activities.

Water quality parameters of Dredged and Undredged area of the lagoon is presented in Table 1. One-way (ANOVA) test indicates that all water quality parameters measured with exception of Turbidity and Nitrate concentration were not significantly different $(\mathrm{P}>0.05)$ between Dredged and Undredged areas.

\section{Discussion}

This study revealed significant differences in water quality parameters and sediments properties from Dredged and Undredged areas, and highly significant relationship between sand dredging and unsustainable ecological utilization of the 
water system.

One way ANOVA test indicate that all water quality parameters measured with exception of Turbidity and Nitrate concentration, were insignificantly different $(\mathrm{P}>0.05)$ between Dredged and Undredged areas. With exception of moisture content other sediment parameters measured were insignificantly different $(P>0.05)$ between Dredged and Undredged areas. Also, the project assessed the impact of dredging activities on the fisheries and fishing activities in the environment, although water parameters are insignificantly affected this is well corroborated by the responses from the respondents ( 50 per cent) stating no effects on fishing activities Figure 2(g). However, turbidity value in this study showed that fishes will be negatively affected due to dredging activities, Table 1 . The people living around the place pay little or no attention to conservation of the area due to unawareness. The sand dredging operators' activities influence negatively on the ecological resources and water composition of the Lagoon.

In comparison to LASEPA standard, physico-chemical parameter except for turbidity and nitrate contents were within acceptable standards as illustrated in Table 2. From the results of the samples analysed, it is therefore apparent that the impact of dredging on water quality is localized and short-term, hence there is no significant change in water composition compared to standard water quality concentrations.

This work shows distribution pattern of metals in surface sediments is generally within permissible limits, however except for Lead which is higher in both Dredged and Undreged areas of the lagoon, following trends in Ria De Aveiro Lagoon in Portugal [28]. A plausible factor for this high level is associated with deposition of petroleum products from motorised out board engines by artisanal fishing folks into the water in both Dredge and Undredged areas.

As COD and BOD results varied strongly with TSS (Table 3) results in this study for both Dredged and Undreged areas were well below permissible limits, apparently an indication that dredging has little influence in organic pollution of the water body, a relatively low COD values was also recorded for the dredging of Bay in Egypt [29]

Ibeshe area is rural wherein most of the dwellers are not informed on the need to conserve the environment and lack access to information on the importance of conservation, Figure 2(e). Hence, there is the need to better information on the essence of environmental conservation.

The result of laboratory analysis conducted coupled with the information deduced from the questionnaires administered on the water samples collected and respondents' responses indicate negative impact on fishery distribution. As a result of high turbid situation generated by dredging activity, [30] opined that decrease in light penetration by between $25 \%$ - 50\% for over a distance of about $12 \mathrm{~km}$ could emanate and this effect could remain persistent for a period of 18 months after dredging activities. Thus, the extent of turbidity impact on the study area established that there are significant changes in fishery distribution. 
It was discovered that the physico-chemical parameter results recorded during the dredging phase of the study location appeared to be lower in concentration and closer to a quality water condition when compared to pre-dredging average values from a $5 \mathrm{~km}$ radius from the study area. Prior to year 2009, a great deal of indiscriminate activities such as effluent discharge from industries and abuse of the water body by riparian community is evident, this perhaps explains the low water quality observed in the pre-dredging phase.

Consequent upon the aforementioned development, Lagos State Government banned all forms of dredging activities in the state and ultimately called for joint monitoring exercise by the Ministry of Waterfront Infrastructure and Development, LASEPA and Ministry of Environment against illegal dredging operations. However, this period of focused routine monitoring, regulation, enforcement and prosecution exercise carried out by the Lagos State Government is believed to be responsible for the relatively stable status of the physico-chemical parameters in the water body.

Aquaculture has a promising future in Lagos State [31], but there are many environmental issues that have to be addressed if it is to realize its full potential. Such environmental issues include aquatic pollution as a result of urbanization and industrialization in the State, in which dredging activity is taking a lead role among others like pesticide run-offs from agricultural land, conflict of land use between aquaculture and industries, tourism and others.

\section{Conclusions}

The research focuses on peoples' perception on the effects of dredging activities on water quality and fishery distribution in Ibeshe waterfront of Ikorodu area of Lagos lagoon. As revealed by the study and previous studies, Ibeshe coastal community is one of the important areas of Ikorodu waterfront. It is a coastal region characterized with long years of sand mining by either manual or mechanical dredging, artisanal fisheries and transportation. However, over the years, these dredging activities have been found to be profit oriented, only on the part of the operators and oftentimes to the detriment of the riparian communities and the environment at large. Consequently, some impacts resulting from this sand mining operation include destruction of wetlands and mangrove swamps, continual turbid appearance of water-body, disappearance of certain phytoplankton and zooplankton including several species of macro-benthos which ultimately affect fishery distribution.

In addition to sand dredging, uncontrolled discharge of domestic and industrial wastes also has pollution implications as they alter concentrations of the water composition and its quality. However, in order to achieve sustainable and environmentally suitable condition of sand dredging activities in Lagos State, it is opined that the policy and regulation governing this operation should be enforced more effectively.

However, this project reveals that dredging activities have altered the lithology 
of the study area and also dredging impact on the ecosystem is low and temporary as nutrients and resources lost as a result of dredging can be regained when the activities is stopped.

In view of the above, a more collaborative work should be encouraged in the area of monitoring, enforcement and environmental regulation amongst relevant Ministries, Departments and Agencies (MDAs) to achieve sustainable dredging operations and relatively stable aquatic ecosystem.

The Ministry of Waterfront Infrastructure and Development saddled with the responsibility to regulate and monitor dredging and other activities along shorelines in Lagos State should ensure the proper management of dredging operations in waterways. This should be accomplished by granting of approvals for dredging operations in accordance with the principles of Ecologically Sustainable Development.

\section{Acknowledgements}

We immensely appreciate Late Dr J.I. Agboola and Mr J.Y. Appia of the University of Lagos and Nigerian Institute for Oceanography and Marine Research respectively for their contributions to this paper.

\section{References}

[1] Central Dredging Association (2009) Dredging and the Environment: Moving Sediments in Natural Systems. CEDA Information Paper. The Netherlands. http://www.dredging.org

[2] Newell, R.C., Seiderer, L. and Hitchcock, D.R. (1998) The Impact of Dredging Works in Coastal Waters: A Review of the Sensitivity to Disturbances and Subsequent Recovery of Biological Resources in the Seabed. Oceanography Marine Biology Annual Review, 36, 809-818.

[3] Caetano, M., Madureira, M.J. and Vale, C. (2003) Metal Remobilisation during Resuspension of Anoxic Contaminated Sediment: Short-Term Laboratory Study. Water Air Soil Pollution, 143, 23-40. https://doi.org/10.1023/A:1022877120813

[4] Vale, C., Ferreira, A., Micaelo, C., Caetano, M., Pereira, E., Madureira, M.J. and Ramalhosa, E. (1998) Mobility of Contaminants in Relation to Dredging Operations in a Mesotidal Estuary (Tagus Estuary, Portugal). Water Science Technology, 37, 25-31.

[5] Monteiro, M.T., Oliveira, R. and Vale, C. (1995) Metal Stress on the Plankton Communities of Sado River (Portugal). Water Research, 29, 695-701.

https://doi.org/10.1016/0043-1354(94)00156-2

[6] Cabrita, M.T., Raimundo, J., Pereira, P. and Vale, C. (2013) Optimizing Alginate Beads for the Immobilisation of Phaeodactylum tricornutum in Estuarine Waters. Marine Environmental Research, 87-88, 37-43. https://doi.org/10.1016/j.marenvres.2013.03.002

[7] Pan, K. and Wang, W.-X. (2012) Trace Metal Contamination in Estuarine and Coastal Environments in China. Science Total Environment, 421-422, 3-16. https://doi.org/10.1016/j.scitotenv.2011.03.013

[8] Rogers, S.I. and Greenaway, B. (2005) A UK Perspective on the Development of Marine Ecosystem Indicators. Marine Pollution Bulletin, 50, 9-19. 
https://doi.org/10.1016/j.marpolbul.2004.10.028

[9] Paerl, H.W., Lexia, M.V., Alan, R.J. and Valerie, W. (2007) Phytoplankton Indicators of Ecological Change in the Eutrophying Pamlico Sound System, North Carolina. Ecological Applications, 17, 88-101. https://doi.org/10.1890/05-0840.1

[10] Ade Sobande and Associates (1998) Dredging Impact Study. Report, Shell Petroleum Development Company of Nigeria (SPDC), Warri.

[11] Ohimain, E.I., Imoobe, T.O.T. and Benka-Coker, M.O. (2002a) Impacts of Dredging on Zooplankton Communities of Warri River, Niger Delta. African Journal of Environmental Pollution and Health, 1, 37-45.

[12] Ohimain, E.I., Benka-Coker, M.O. and Imoobe, T.O.T. (2002b) Algal Bloom in a Newly Dredged Canal in a Tropical Mangrove Ecosystem. In Press.

[13] Ohimain, E.I., Benka-Coker, M.O. and Imoobe, T.O.T. (2002c). Impacts of Dredging on the Abundance and Diversity of Benthic Invertebrates in the Niger Delta. UNIBEN Digest. In Press.

[14] US Geological Survey (2004) Chesapeake Bay River Input Monitoring Program. http://va.water.usgs.gov/chesbay/RIMP/waterchem.html

[15] Moss, B., Madgwick, J. and Phillips, G. (1996) A Guide to the Restoration of Nutrient Enriched Shallow Lakes. W W Hawes, UK.

[16] Jain, C.K. and Ram, D. (1997) Adsorption of Metal Ions on Bed Sediments. Hydrological Science Journal, 42, 713-723. https://doi.org/10.1080/02626669709492068

[17] Nielsen, P. (2009) Coastal and Estuarine Processes. World Scientific, Singapore. https://doi.org/10.1142/7114

[18] Manap, N. and Voulvoulis, N. (2015) Environmental Management for Dredging Sediments-The Requirement of Developing Nations. Journal of Environmental Management, 147, 338-348.

[19] Ohimain, E.I. (2004) Environmental Impacts of Dredging in the Niger Delta. Terra et Aqua, 97, 9-19.

[20] Sammut, J. and Lines-Kelly, R. (1996) An Introduction to Acid Sulfate Soils.

[21] Ohimain, E.I. (2003a) Environmental Impacts of oil Mining Activities in the Niger Delta Mangrove Ecosystem. Proceedings of the International Mine Water Association Congress, Johannesburg, October 2003, 503-517.

[22] Ohimain, E.I. (2003c) Available Options for the Bioremediation and Restoration of Abandoned Pyritic Dredge Spoils Causing the Death of Fringing Mangroves in the Niger Delta. The International Biohydrometallurgy Symposium, Athens, September 2003, 475-481.

[23] Ohimain, E.I. (2001) Bioremediation of Heavy Metal Contaminated Dredged Spoil from a Mangrove Ecosystem in the Niger Delta. PhD Thesis, School of Postgraduate Studies, University of Benin, Benin City, $341 \mathrm{p}$.

[24] Burford, M.A. and O’Donohue, M.J. (2006) A Comparison of Phytoplankton Community Assemblages in Artificially and Naturally Mixed Subtropical Water Reservoirs. Freshwater Biology, 51, 973-982. https://doi.org/10.1111/j.1365-2427.2006.01536.x

[25] Lucas, C.H., Widdows, J., Brinsley, M.D., Salkeld, P.N. and Herman, P.M.J. (2000) Benthic-Pelagic Exchange of Microalgae at a Tidal Flat. 1. Pigment Analysis. Marine Ecology Progress Series, 196, 59-73. https://doi.org/10.3354/meps196059

[26] APHA-AWWA-WPCF (2005) Standard Methods for the Examination of Water and Wastewater. 15th Edition, R.R. Donnelley \& Sons Company, Chicago, 547. 
[27] FAO/SIDA (1983) Manual of Methods in Aquatic Environmental Research, Part 9. Analyses of Metals and Organochlorines in Fish. FAO Fisheries Technical Paper, 212.

[28] Martins, M.V.A., Laut, L., Duleba, W., Zaaboub, N., Aleya, L., Terroso, D.L., Sequeira, C., Pena, A., Rodrigues, M.A. and Rocha, F. (2017) Sediment Quality and Possible Uses of Dredged Materials: The Ria de Aveiro Lagoon Mouth Area (Portugal). Journal of Sedimentary Environments, 2, 149-166.

[29] Mostafa, Y.E.S. (2012) Environmental Impacts of Dredging and Land Reclamation at Abu Qir Bay, Egypt. Ain Shams Engineering Journal, 3, 1-15. https://doi.org/10.1016/j.asej.2011.12.004

[30] Reavell, P.E. (1997) The Effect of Dredging on Light Penetration in the Boro River, Okavango Delta, Botswana, from 1972 to 1975. Water $S A, 23,109$.

[31] Akintola, S.L., Jimoh, A.A., Owodehinde, F.G., Whenu, O.O. and Fakoya, K.A. (2009) Environmental Threat to the Development of Aquaculture in Lagos State, Nigeria. European Journal of Scientific Research, 34, 337-347. 